\title{
Phytochemicals: As Alternate to Chemical Pesticides for Insects Pest Management
}

\author{
A Jeyasankar* \\ Entomology Research Laboratory, Government Arts College, India
}

Submission: May 05, 2017; Published: May 23, 2017

"Corresponding author: A Jeyasankar, Entomology Research Laboratory, Government Arts College, Coimbatore-641 018, Tamilnadu, India, Email: sankar.alagarmalai@gmail.com

\section{Mini Review}

One of the major challenges that mankind confronts is providing adequate food to the rapidly growing population of the world, which is calculated to reach an estimate of 8 billions of people in the year 2020. In order to rationalize this, it is mandatory to increase food production through crop protection, which mainly depends on plants. These are often over whelmed by many insect pests and diseases among which insects play a predominant role. Commercially available chemical pesticides are currently the most effective means of pest control programme. However, the indiscriminate use of these chemical substances have not only caused adverse effects on mammals health, but have also caused deleterious impact on the other beneficery members of the ecosystem and the environment in which they are immersed. Chemical pesticides have also responsible for pest resurgence and producing resistance among pathogens [1]. Henceforth, one of the best alternatives for insect pests control and to mitigate their attack is using phytochemicals. There is no doubt that naturally, many plant secondary metabolites (phytochemicals) affect insect behavior, development and reproduction. Identifying plant phytochemicals which are interfering with the insect physiology through the scree ingis an alma mater in understanding the effect of plants on insect life at the molecular level.

\section{Combating with insects using plant secondary metabolites [2]}

Collectively, more than 10,000 low-molecular mass compounds are known as secondary metabolites of plants. Simple phenols, phenylpropanoidderivatives, coumarins, flavonoids, tannins, quinones, ethereal oils, isoprene derivatives (iridoids, sesquiterpene lactones, diterpenes, triterpenesaponins,steroid saponins), cardiotonicheterosides, alkaloids (pirolidone, pirolysine andpiperidine alkaloids, kinolisidine alkaloids, kinoline alkaloids, isokinoline, indole, purine, diterpene and steroide alkaloids), and cyanogene glycosides are examples of such compounds. This diversity results in part from an evolutionary process driven by selection for acquisition of improved defense against pests and diseases.

\section{Advantages of plant based products [3]}

i. Generally, botanical insecticides do not persist in the environment and are quickly degraded by various environmental factors such as temperature, ultraviolet light, rainfall, etc.

ii. Synthetic chemical insecticides are needed because they are not always as effective as other synthetic insecticides, repeated applications may be needed to achieve the desired result.

iii. Because some botanical insecticides are insect growth regulators, they are only effective against the immature stages of insects.

iv. They normally do not exhibit an immediate knockdown effect and the insect pests might continue to feed.

v. However, due to their repellent effects, insect feeding may be reduced.

vi. The presence of some insects on the plants may hide the real effectiveness of some botanical insecticides.

vii. However, the damage caused to the plants was significantly reduced in the treated plants.

viii. In addition, most botanical insecticides or plant extracts are compatible with other insecticides, and are useful in integrated pest-management programs.

At present, only a handful numbers of botanical insecticides are commercially available for farmers, and most of them are neem-or azadirachtin-based. Large-scale production at competitive prices is not currently feasible for most commercial products, but it islikely that major breakthroughs in botanical pesticide technology will necessitate the use of botanical pesticides for fresh vegetable production. Nevertheless, like 
other bio pesticides, botanical insecticides will completely replace synthetic chemical insecticides in the near future. As anticipated by Hall \& Menn [4], the botanical pesticide market will grow at an annual rate of $10 \%$ as compared with $1-2 \%$ increase for synthetic chemical insecticides. We anticipate that botanical and bio pesticides will be used at least as supplements to synthetic insecticides or as part of pesticide rotations to retard the onset of resistance.

\section{References}

1. Carpinella MC, Defago MT, Valladares G, Palacios SM (2006) Role of
Melia azedarach L. (Meliaceae) for the control of insects and acari: present status and future prospects. In: Rai \& Carpinella (Eds.), Naturally Occurring Bioactive Compounds. Elsevier BV, p. 81123.

2. Cowan MM (1999) Plant products as antimicrobial agents. Clin Microbiol Rev 12(4): 564-582.

3. Liu T, Xu H, Luo W (2006) Opportunities and potentials of botanica extracts and products for management of insect pests in cruciferous vegetables. In: Rai \& Carpinella (Eds.), Naturally Occurring Bioactive Compounds. Elsevier BV, pp. 171-197.

4. Hall FR, Menn JJ (1999) Method in biotechnology, 5: Biopesticides. Humana Press, Totowa, NJ, USA.

\section{Your next submission with Juniper Publishers} will reach you the below assets

- Quality Editorial service

- Swift Peer Review

- Reprints availability

- E-prints Service

- Manuscript Podcast for convenient understanding

- Global attainment for your research

- Manuscript accessibility in different formats

( Pdf, E-pub, Full Text, Audio)

- Unceasing customer service

Track the below URL for one-step submission https://juniperpublishers.com/online-submission.php 